\title{
Bacterial Artificial Chromosome-Based Experimental Strategies in the Field of Developmental Neuroscience
}

\author{
Youhei W. Terakawa ${ }^{1,2}$, Yukiko U. Inoue ${ }^{1}$, \\ Junko Asami ${ }^{1}$ and Takayoshi Inoue ${ }^{1}$ \\ ${ }^{1}$ Department of Biochemistry and Cellular Biology, National Institute of Neuroscience \\ National Center of Neurology and Psychiatry, Kodaira, Tokyo \\ ${ }^{2}$ Department of Electrical Engineering and Bioscience, Graduate School of Advanced \\ Science and Engineering, Waseda University, Shinjuku-ku, Tokyo \\ Japan
}

\section{Introduction}

Bacterial artificial chromosomes (BACs) constitute minimal components of various whole genome-sequencing projects, including our own. The recent innovation of efficient recombinogenic bacterial strains allows systematic BAC modifications (i.e. recombineering; Reviewed in Copeland et al., 2001), setting BACs as an ideal experimental basis for functional genomics with their broad coverage of transcriptional regulatory elements. For instance, in the field of neuroscience, the GENSAT project extensively modified mouse BAC clones, covering gene transcriptional units preferentially expressed in the nervous system, and generated hundreds of BAC transgenic (Tg) mouse lines from those modified BACs (Gong et al., 2003). These BAC-Tg lines successfully recapitulated complex gene expression profiles in the nervous system (Gong et al., 2003), providing a rigid analytical platform so as to be able to answer the fundamental question of how tens of millions of neurons and thousands of cell-types can become elaborate interconnected circuitries in the brain by using only twenty-thousand sets of gene transcriptional activities.

Classic cadherins are adhesion molecules at the cell-cell adherence junction and the neuronneuron synapse peri-active zone (i.e. puncta adherentia) whose expression differentially delineates elaborated cytoarchitectures, such as layers and nuclei that constitute the basis for neural circuit formation in the vertebrate nervous system (Takeichi, 1995; Takeichi and Abe, 2005). Classic cadherins have 20 subclass members encoded by different genes, with each subclass harbouring distinct cell adhesiveness (Takeichi, 1995). In the in vitro aggregation assay system, it has been demonstrated that dissociated cells expressing the same sets of the classic cadherin subclass at a same level tend to make aggregates depending upon the calcium ion (Nose et al., 1988; Steinberg et al., 1994). Noticeably, in the developing nervous system, each classic cadherin subclass shows unique expression patterns, and such expression profiles are dynamically regulated during morphogenetic processes (Gumbiner, 2005; Redies, 2000). For instance, during chickens' early neural development, prospective neural tissue begins to express $\mathrm{N}$-cadherin and, at the interface between the $\mathrm{N}$-cadherin 
expressing cells and the surface ectodermal cells with E-cadherin expression, a Cadherin-6B positive, N-cadherin negative domain appears to segregate neural crest cells. Once they have emigrated from the neural plate/tube, neural crest cells finally begin to express Cadherin-7. This dynamical cadherin class switch is critical to the regulation of neurulation dynamics, since ectopically expressed $\mathrm{N}$-cadherin perturbs the neural tube segregations from the ectoderm and/or the neural crest cell emigrations (Fujimori et al., 1990; Nakagawa \& Takeichi, 1998). It is thus suggested that spatio-temporally regulated cadherin expression plays a pivotal role in animal morphogenetic processes.

While the physiological significance of differential cadherin expression profiles and/or cadherin class switches in neural development has been implicated, their gene regulatory mechanisms are largely unknown, due to the huge size and complex organisation of cadherin gene structures. Understanding the regulatory mechanisms for classic cadherin expression is crucial from a clinical point of view, as many cancer cells lose precise expression profiles of cadherins, resulting in the hyper-growth of cells and/or cell metastasis (Takeichi, 1995).

In our early studies, we have applied BAC-based technologies so as to screen gene regulatory patterns for a subclass of classic cadherins, cadherin-6 (Cdh6) whose gene structure is too large and complex for the identification of its promoter/enhancers by conventional methods. We succeeded in finding out that different genomic territories, located as far as 100-kbp upstream or downstream from the transcription start-site, is required for $C d h 6$ expression at the defined time and place (Inoue et al., 2008a; Inoue et al., 2008b). Here, we extend the enhancer screening and reveal that a 6-kbp sized 3 prime intergenic region is critical in order to yield Cdh6 expression along the somatosensory barrel, a distinct cytoarchitecture of the mouse cerebral cortex, at around postnatal day 7 (P7). Additionally, by taking advantage of the Cdh6 enhancer/promoter activity identified, we establish a BAC $\mathrm{Tg}$ mouse line in which somatosensory barrels are stably illuminated by exogenous green fluorescent protein (GFP) expression, allowing us to suggest the roles of the retinoic acid (RA) related signalling pathway during cortical barrel field development and/or patterning. These results clearly demonstrate the strictly divisible $C d h 6$ regulatory pattern along functional brain units, and the value of BAC-based experimental strategies in the field of developmental neuroscience.

\section{Protocols}

\subsection{BAC modification via homologous recombination in bacterial cells}

The recombinogenic bacterial strain EL250 (Lee et al., 2001) was used in the present study. For the homologous recombination, $\sim 1-\mathrm{kbp}$ homology arms were amplified from the BAC clone of interest $(=R P 23-78 N 21$ in this study) by means of a polymerase chain reaction (PCR), and were cloned into a conventional TA cloning vector (pGEM-T-Easy; Promega). For homologous recombination, beta-galactosidase (LacZ) and a growth-associated protein43 tagged enhanced green fluorescent protein (GAP43-EGFP) gene expression cassette were inserted into the BAC clone of interest; a LacZ/GAP-EGFP gene expression cassette and a gene cassette for clone selections (e.g. ampicillin resistant gene, kanamycin resistant gene, etc.) were cloned in between the homology arms and the fragment containing arms as well as reporter/selection gene cassettes which were purified by means of agarose gel electrophoresis after complete digestion with proper restriction enzymes. For homologous recombination mediated deletion of given territories from the BAC clone of interest, only the selection cassette was cloned in between the homology arms and the portion containing 
arms, and the selection cassette was isolated as described above. The selection cassette was put in between two FRT sites for its eventual excision by the inducible Flpe gene (see below).

The recombination system in EL250 cells (Lee et al., 2001) was activated via heat shock, and their electroporation-competency (EP) was conferred on ice so as to maintain the recombinogenic activity. Briefly, EL250 cells that harbour the BAC clone of interest were precultured in $50 \mathrm{ml}$ of LB without antibiotic at $32^{\circ} \mathrm{C}$, until an optical density of $600 \mathrm{~nm}\left(\mathrm{OD}_{600}\right)$ was reached at 0.5 . By adding $2.5 \mathrm{ml}$ of the overnight saturated culture to $50 \mathrm{ml}$ of $\mathrm{LB}$, it normally took $\sim 90 \mathrm{~min}$ to obtain $0.5 \mathrm{OD}_{600}$ in the shaking culture at $32^{\circ} \mathrm{C}$. Then, $15 \mathrm{ml}$ of the culture was heat-shocked at $42^{\circ} \mathrm{C}$ for $15 \mathrm{~min}$ in a water bath with the shaker's agitation, while another $15 \mathrm{ml}$ was maintained in the shaking culture at $32^{\circ} \mathrm{C}$ as the control. Both of the cultures were subsequently placed on ice for $15 \mathrm{~min}$, centrifuged, and quickly washed three times by ice-cold water in order to draw the electro-competency for the heat-shocked cells. A few hundred nano-grams of the resultant purified fragment was then electroporated with a $1 \mathrm{~mm}$ gap cuvette by $1.8 \mathrm{kV}$ (BioRad) into the EP-competent cells, pre-incubated for 2 hours at $32^{\circ} \mathrm{C}$, and selected on an LB agar-plate containing $12.5 \mu \mathrm{g} / \mathrm{ml}$ chloramphenicol and $12.5 \mu \mathrm{g} / \mathrm{ml}$ Kanamycin/Ampicillin for $\sim 40$ hours at $32^{\circ} \mathrm{C}$. Starting with the culture of EL250 cells which harboured the BAC clone of interest, from $15 \mathrm{ml}$ we obtained $\sim 100$ colonies from the heatshocked cell plate after the EP, with more than $90 \%$ of the colonies containing precisely the modified BAC clone. To excise the selection cassette from the modified BACs, arabinose was added to the log phase liquid culture of the selected clone, with the correct recombinant BACs at $0.1 \% \mathrm{v} / \mathrm{v}$ for 1 hour at $32^{\circ} \mathrm{C}$ so as to sufficiently induce the Flpe gene in EL250 cells. The loss of the selection cassette was monitored on the L-plate containing the antibiotic for the selection cassette. Homologous recombination events were always verified by PCR and/or electrophoresis after purification of the BAC DNA from each colony, as mentioned below.

\subsection{BAC purification and evaluation}

In order to obtain sufficient BAC DNA for PCR based clone selections, pulse field gel electrophoresis (PFGE) mediated evaluations and/or direct sequencing, around $3 \sim 6 \mathrm{ml}$ liquid culture was inoculated for each colony. Prior to the purification of the BAC DNA, 400 $\mu \mathrm{l}$ of the saturated culture was mixed with $80 \mu \mathrm{l}$ of $40 \%$ glycerol solution and stored at $-80^{\circ} \mathrm{C}$. The general protocol to purify the plasmid DNA was modified for the BAC DNA as follows: a bacterial cell pellet from the saturated culture (up to $3 \mathrm{ml}$ ) was collected into a $1.5 \mathrm{ml}$ tube by serial centrifugations, and was suspended into $100 \mu \mathrm{l}$ of solution I. The suspension was gently lysed by adding $200 \mu \mathrm{l}$ of freshly prepared solution II (slowly inverting the tube four times so as to make the suspension nearly transparent) and carefully neutralised by adding $150 \mu \mathrm{l}$ of cold solution III (gently inverting the tube twice to mix the contents evenly). After centrifugation at $15,000 \mathrm{rpm}$ for $10 \mathrm{~min}$ at $4^{\circ} \mathrm{C}$, the supernatant was overlaid on $500 \mu \mathrm{l}$ of phenol chloroform mixture, and the content was evenly blended by gently shaking the tube three times. After centrifugation at 15,000 rpm for $5 \mathrm{~min}$ at room temperature, the upperlayer was transferred to a $1.5 \mathrm{ml}$ tube filled with $350 \mu \mathrm{l}$ of isopropanol, mixed and reserved at $-30^{\circ} \mathrm{C}$ for at least $30 \mathrm{~min}$. After centrifugation at $15,000 \mathrm{rpm}$ for $10 \mathrm{~min}$ at $4^{\circ} \mathrm{C}$, the pellet including the BACs and RNA was washed with $75 \%$ ethanol and dissolved into $30 \mu \mathrm{l}$ of distilled water $(\mathrm{DW})$ containing RNase at $60^{\circ} \mathrm{C}$ for $10 \mathrm{~min} .7 .5 \mu \mathrm{l}$ of the BAC solution can be used for visualising the DNA fragment on normal $0.6 \%$ agarose/TAE gel electrophoresis or $1 \%$ agarose/TBE PFGE. For sequencing, polyethyleneglycol-based precipitation was carried 
out overnight at $4^{\circ} \mathrm{C}$, and the pellet was dissolved into DW to measure the optical density at $\mathrm{OD}_{260}$ by NanoDrop (Thermo Fisher Scientific).

To obtain good amounts of BAC DNA with high quality for trans-genesis, a $\mathrm{CsCl}$ density gradient ultracentrifugation-based purification method or a purification kit (NucleoBond BAC 100, Macherey-Nagel) were utilised. For CsCl purification, 1,500 ml LB was inoculated for each clone from the glycerol stock. For the kit, $250 \mathrm{ml}$ of the culture was harvested and BAC DNA was purified as the manufacture's protocols recommended.

\subsection{BAC trans-genesis}

All the animal experiments in this study conform to Japanese governmental guidelines and have been approved by the Animal Care and Use Committee of the National Institute of Neuroscience (Projects 2007022 and 2011007). For microinjection of BAC DNA into fertilised mouse eggs, an engineered BAC clone was linearised by PI-SceI, purified by ethanol precipitation and dialysed on a filter membrane (Millipore VMWP-pore size $0.05 \mu \mathrm{m}$ ) to the BAC injection buffer, containing 10 mM Tris-HCl pH 7.5, 0.1 mM EDTA, $100 \mathrm{mM} \mathrm{NaCl}, 30$ $\mu \mathrm{M}$ spermine (tetrahydrochloride; Sigma S-1141) and $70 \mu \mathrm{M}$ spermidine (trihydrochloride; Sigma S-2501) for 2 hours. The quality of the DNA was evaluated by NanoDrop (Thermo Fisher Scientific) and the linearised BAC solution was diluted to $\sim 2 \mathrm{ng} / \mu \mathrm{l}$ by the BAC injection buffer and was microinjected into pronuclei of the mouse-fertilised eggs prepared from the superovulated B6C3F1 mouse strain (SLC, Japan or Charles River, Japan). Generally, 10 transgenic founders were obtained from $\sim 200$ eggs injected.

For the genotyping of the transgenic mouse founders or embryos, tails or yolk sacs were collected and treated with $100 \mu \mathrm{g} / \mathrm{ml}$ Proteinase $\mathrm{K}$ (Wako, Japan) at $55^{\circ} \mathrm{C}$ for several hours in a tail buffer containing $10 \mathrm{mM}$ Tris pH7.5, $100 \mathrm{mM} \mathrm{NaCl}, 1 \mathrm{mM}$ EDTA and 1\% SDS. After heating at $95^{\circ} \mathrm{C}$ for $5 \mathrm{~min}$, these samples were extracted once with a phenol chloroform mixture and stored at $-20^{\circ} \mathrm{C}$. To determine their genotypes, PCR was performed with the primer sets covering exogenous gene cassettes, such as LacZpA. The presence of RP23/24 vector sequences immediately upstream or downstream of the PI-SceI site was further examined by PCR so as to minimise the possibility that fortuitous large deletions fell onto the BACs which had been integrated into the chromosome.

\subsection{The detection of beta-galactosidase activities or green fluorescent protein in brain slice preparations}

In order to make brain slices only for the mice harbouring BAC-beta-galactosidase transgenes, we devised the rapid genotyping method for BAC transgenic pups to be finished during the morning of the day for brain dissection and slicing, as transgenic mice were always kept with the transgene being hemizygous, and were inter-crossed with B6C3F1 wild type mice (anticipating the delivery of transgenic pups at a $50 \%$ probability). Briefly, the cranial part of a mouse pup was anesthetising on ice and was placed into a chamber of the 12well dish and filled with ice-cold Tyrode's solution. The tail was cut at the same time, and put into $100 \mu \mathrm{l}$ of tail buffer containing $100 \mu \mathrm{g} / \mathrm{ml}$ of Proteinase K (see above). After finishing the collecting of the cranial parts and tails from a litter, the tail samples were incubated at $55^{\circ} \mathrm{C}$ for $\sim 40 \mathrm{~min}$ with thorough voltexing in every $10 \mathrm{~min}$. The tail samples were heated at $95^{\circ} \mathrm{C}$ for $5 \mathrm{~min}$ and extracted once with a phenol chloroform mixture. A PCR for genotyping was then performed, as described earlier (Inoue et al., 2008). While the PCR was running, the 
whole brain was dissected out from the cranial part and fixed in a phosphate-buffered saline (PBS pH7.4) containing 1\% paraformaldehyde, $0.1 \%$ glutalaldehyde, $2 \mathrm{mM} \mathrm{MgCl} 2,5 \mathrm{mM}$ EGTA and 0.02\% Igepal CA-630 (NP-40; Sigma) for $90 \mathrm{~min}$ on ice. After a washing for the fixative by the washing buffer (WB: PBS containing 0.02\% Igepal CA-630), these whole brain samples were kept in WB on ice. In the afternoon, we embedded only those brains confirmed to be positive for the transgene by PCR in $2 \%$ agarose/PBS, and made $550 \mu \mathrm{m}$ slices by using a microslicer (DTK-3000, D.S.K., Kyoto). The slices were then incubated in the staining solution, containing $5 \mathrm{mM} \mathrm{K} 3 \mathrm{Fe}(\mathrm{CN})_{6}, 5 \mathrm{mM} \mathrm{K}{ }_{4} \mathrm{Fe}(\mathrm{CN})_{6} \cdot 3 \mathrm{H}_{2} \mathrm{O}, 2 \mathrm{mM} \mathrm{MgCl}, 0.01 \%$ sodium deoxycholate, $0.02 \%$ Igepal CA-630 and $0.1 \%$ X-gal (Wako, Japan) for several hours at $37^{\circ} \mathrm{C}$ with gentle agitations. The colour-detection was stopped by several washings with WB, and samples were post-fixed overnight in a PBS containing $5 \mathrm{mM}$ EDTA, 1\% paraformaldehyde, $0.1 \%$ glutalaldehyde and $0.02 \%$ Igepal CA-630 at $4^{\circ} \mathrm{C}$. After washings with $\mathrm{WB}$, the samples were finally stored at $4^{\circ} \mathrm{C}$ in a PBS containing $1 \mathrm{mM}$ EDTA and $0.02 \%$ Igepal CA-630. For analysis, stained slice samples were put on $2 \%$ agarose/PBS plate filled with a PBS solution and flattened by a cover glass. Sample images were then captured under binocular microscope (MZ8, Leica) equipped with a CCD camera (DFC300FX, Leica) and printed out by using a video printer (SCT-CP7000, Mitsubishi, Japan).

For preparing the brain slices for the mice that harbour BAC-GAP43-EGFP transgenes, the whole brain was dissected out and illuminated under a fluorescent binocular microscope (FLIII, Leica) so as to easily select the transgenic brain. Transgenic brains were fixed in $2 \%$ paraformaldehyde/PBS for 1 hour and embedded in 2\% agarose/PBS. $550 \mu \mathrm{m}$ slices were then made by using the microslicer and photographs were taken under the microscope (FLIII, Leica) equipped with a CCD camera (DFC300FX, Leica).

\subsection{Retinoic acid administration to mouse embryos and pups}

To administer retinoic acid (RA; Sigma \#2625 or ITSUU laboratory), the stock solution was prepared with a concentration of $30 \mathrm{mg} / \mathrm{ml}$, and $1 \mathrm{ml}$ of the 1/1000 diluent (30 $\mu \mathrm{g})$ was intraperitoneally administrated to the mother or the pups, per $1 \mathrm{~g}$ of body weight (Smith et al. 2001).

\subsection{Solutions used in the present study}

LB: One litre of LB solution contains $10 \mathrm{~g}$ of Tryptone (BD Biosciences), $5 \mathrm{~g}$ of Yeast Extract (BD Biosciences), $5 \mathrm{~g}$ of $\mathrm{NaCl}$ and $4 \mathrm{ml}$ of $1 \mathrm{~N} \mathrm{NaOH}$. The solution is stored at room temperature after autoclave.

Solution I for BAC purification: This solution contains $50 \mathrm{mM}$ glucose, $25 \mathrm{mM}$ Tris-Cl (pH 8.0) and $10 \mathrm{mM}$ EDTA ( $\mathrm{pH} 8.0)$. The solution was stored at room temperature.

Solution II for BAC purification: This solution contains 1\% sodium dodecyl sulphate (SDS) and $0.2 \mathrm{~N} \mathrm{NaOH}$. To obtain a good amount and the purity of the BACs, the solution was freshly prepared from $10 \%$ SDS and $2 \mathrm{~N} \mathrm{NaOH}$ stock solutions stored at room temperature.

Solution III for BAC purification: $3 \mathrm{M}$ potassium acetate was dissolved into distilled water and the $\mathrm{pH}$ is adjusted with formic acid to 4.8 . We store the solution at $-20^{\circ} \mathrm{C}$.

Phenol Chloroform mixture: $10 \mathrm{mM}$ Tris-Cl saturated phenol solution was mixed with the 0.96 volume of chloroform and 0.04 volume of isoamyl alcohol. The mixture was stored at $4^{\circ} \mathrm{C}$. 
PBS: One litre of 10x PBS stock contains $80 \mathrm{~g}$ of NaCl, $2 \mathrm{~g}$ of $\mathrm{KCl}, 11.5 \mathrm{~g}$ of $\mathrm{Na}_{2} \mathrm{HPO}_{4}$ and $2 \mathrm{~g}$ of $\mathrm{KH}_{2} \mathrm{PO}_{4}$. We sterilised the stock solution by autoclaving and stored it at room temperature.

TAE: One litre of 50x TAE solution contains $242 \mathrm{~g}$ of Tris- $\mathrm{Cl}, 57.1 \mathrm{ml}$ of $\mathrm{CH}_{3} \mathrm{COOH}$ and 100 $\mathrm{ml}$ of $0.5 \mathrm{M}$ EDTA (pH8.0).

TBE: One litre of 10x TBE solution contains $108 \mathrm{~g}$ of Tris-Cl, $55 \mathrm{~g}$ of boric acid and $40 \mathrm{ml}$ of 0.5M EDTA (pH8.0).

Tyrode's solution: Five litres of Tyrode's solution contains $40.0 \mathrm{~g}$ of $\mathrm{NaCl}, 1.0 \mathrm{~g}$ of $\mathrm{KCl}, 1.0 \mathrm{~g}$ of $\mathrm{CaCl}_{2}, 1.05 \mathrm{~g}$ of $\mathrm{MgCl}_{2} \cdot 6 \mathrm{H}_{2} \mathrm{O}, 0.285 \mathrm{~g}$ of $\mathrm{NaH}_{2} \mathrm{PO}_{4} \cdot 2 \mathrm{H}_{2} \mathrm{O}, 5.0 \mathrm{~g}$ of $\mathrm{NaHCO}_{3}$ and $5.0 \mathrm{~g}$ of glucose. To avoid the possible precipitation of salts, we added these reagents in this order and sterilised by filtration and stored at $4^{\circ} \mathrm{C}$.

\section{Results and discussions}

\subsection{Cdh6 gene expression along cortical layer IV neurons in the mouse primary somatosensory barrel field is regulated by an inter-genic region}

The cerebral cortex (also called the 'neocortex' or the 'isocortex') is a mammal-specific brain region with layered cellular organisation in its radial direction (Rakic, 1988). It can further be subdivided into functional areas in its tangential direction, with each area harbouring distinct layer components, constituting fundamental units for higher brain functions that are unique to mammals (O'Leary et al., 2007). How this characteristic brain region can emerge during development as well as through evolution has been one of the important research subjects in the field of neuroscience; however, little is known about the genetic cascade required to elaborate the intricate cytoarchitecture in the cerebral cortex. In this context, classic cadherins have very unique features in their expression patterns: each cadherin subclass shows a distinct cortical layer and/or area specificity at the perinatal stages in mouse and other mammalian species, such as ferrets and humans (Krishna-K et al., 2009; Suzuki et al., 1997; Wang et al., 2009). Classic cadherins might, therefore, provide ideal genetic clues in systematically understanding the molecular mechanism of cortical development.

In the previous studies, we have focused on mouse cadherin-6 (Cdh6), one of classic cadherin subclasses whose expression demarcates subsets of cortical layers and/or areas (Suzuki et al., 1997; Inoue et al., 1998), and we found out that a $58 \mathrm{kbp}$ long 3 prime territory to mouse Cdh6 gene (Segment $X$ in Inoue et al., 2008a) is required for its mRNA expression along the cortical layer IV-barrel neurons in the primary somatosensory area (S1) at postnatal day 7 (P7; Inoue et al., 2008b; our unpublished data). In the present study, we sought to further narrow down the responsible territory for the expression by systematically deleting genomic regions from the reporter modified BAC clone that can recapitulate $C d h 6$ expression in S1-barrel layer IV neurons at P7. To this end, we first referred to the evolutionary conserved region (ECR) browser in which conserved genomic regions among various species are aligned and annotated (http://ecrbrowser.dcode.org). Compared with human and dog genome sequences, as many as 60 ECRs - with more than $70 \%$ similarities in a window larger than $100 \mathrm{bp}$ - were found in Segment $X$ (data not shown), and we roughly divided Segment $X$ into three regions (regions a $\sim$ c in Figure 1) by means of ECR locations. We then sought to differentially delete two of the regions in Segment $X$ from the reporter modified BAC clone RP23-78N21 so as to effectively narrow down the responsible territory (Asami et al., 2011; Constructs \#1 and \#2 in Fig. 1). We subsequently obtained three 


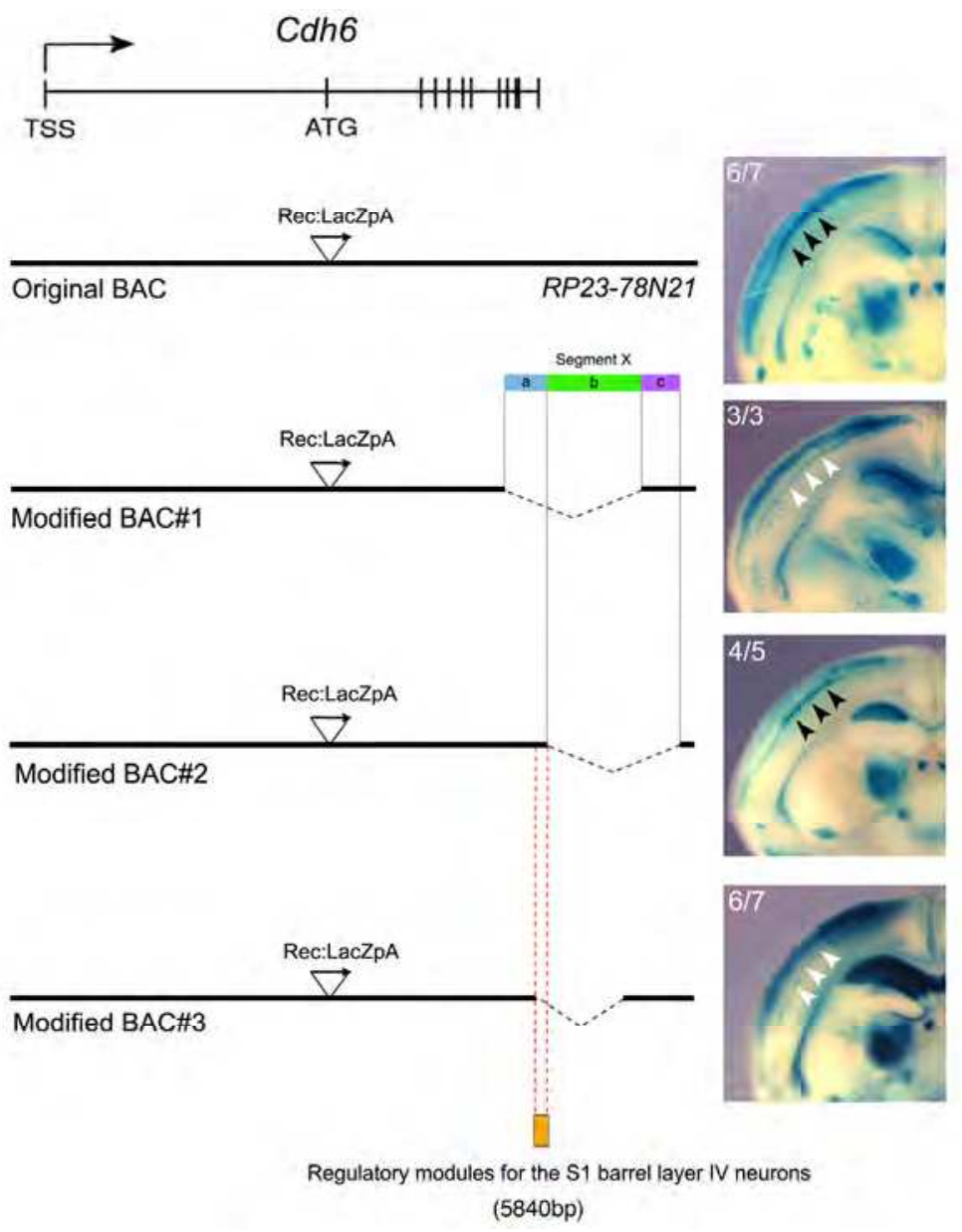

Fig. 1. An intergenic segment of mouse $C d h 6$ is found to be necessary for the postnatal barrel area specific expression in the cerebral cortex.

The uppermost part of the figure indicates the genomic structure of mouse $C d h 6$, with its exons being designated by short vertical lines. ATG, translation start site; TSS, transcription start site. A BAC clone RP23-78N21 is initially modified to harbour a beta-galactosidase gene cassette and a SV40 polyadenylation signal $(\operatorname{LacZpA})$ in a frame to the $C d h 6$ gene via homologous recombination (Rec) in a recombinogenic bacterial strain. This original BAC is further engineered by homologous recombination so as to generate deletion constructs $\# 1 \sim \# 3$. Note that transgenic (Tg) mice with original BACs and construct \#2 strongly recapitulate the somatosensory barrel-specific expressions (black arrow heads), while those with constructs \#1 and \#3 do not yield the expression at the postnatal day 7 (P7; white arrow heads). From these results, a 5840-bp territory (orange box) is determined to be a critical regulatory region for the barrel-specific expression of Cdh6 at P7. At the upper left corner of each panel, the ratio of brain samples exhibiting reproducible reporter expression over the total number of independent transgenic mouse lines generated is noted. 
stable, independent BAC transgenic (Tg) mouse founders from Construct \#1 and five from Construct \#2. In the former founders, none of them recapitulated the reporter expression in S1-barrel layer IV neurons (Fig. 1, white arrow heads), which are strongly marked by the original BAC trans-genesis (Fig. 1, black arrow heads). In contrast, four out of five founders reproduced the intense expression profile of S1-barrel layer IV neurons, while one of them showed no reporter expression in the brain (probably due to the positional effect of the BACs' integration site). From these results, it is strongly suggested that the most 5 prime third of Segment $X$ (region a in Fig. 1) is responsible for Cdh6 expression in the S1-barrel layer IV neurons at P7.

In order to further to narrow down the responsible territory, we designed the Construct \#3 in which a fragment containing the most 3 prime third of region a is excluded from the original BACs. Among seven Tg founders generated from Construct \#3, we could not observe the intense reporter expression of S1-barrel layer IV neurons at all (white arrow heads in Fig. 1), while we found that neurons in the other cortical layers (i.e. layers II/III) and/or areas at P7 maintained their conspicuous expression compared to the original Cdh6BAC-Tg lines (Fig. 1). Taken together, we concluded that a 5,884 bp territory containing 11 ECRs is required for Cdh6 expression in S1-barrel layer IV neurons at P7.

To our knowledge, this is the first time that a distinct gene regulatory fragment for a defined layer and/or area has been observed, suggesting that separable genetic programs may serve the pattering of each cortical layer and/or area during development. The further characterisation of the gene regulatory elements that directly interact with the $5,884 \mathrm{bp}$ territory would be an important next step in understanding how the cortical layer and/or area identity is strictly determined during development. In this connection, it is noticeable that the 5,884 bp territory contains many of the transcription factor binding motifs, such as RORbeta, whose expression is already known to be restricted to defined sets of cortical layers and/or areas (Dye et al., 2011; Hirokawa et al., 2008; Nakagawa \& O'leary, 2003). Since recent reports suggest that RORbeta harbours an instructive role in elaborating barrel cytoarchitecture and/or circuitries (Jabaudon et al., 2011), it would be of great interest to rigorously evaluate how these transcription factors are involved in establishing Cdh6 expression along S1-barrel layer IV neurons at P7 which might have functional significance in driving cell segregations to form and/or maintain the barrel cytoarchitecture.

\subsection{Retinoic acid (RA) related cell signalling machineries might be involved in the cortical barrel patterning}

RA signalling regulates many of the morphogenetic events at the early embryonic stage, such as A-P axis formation, the establishment of L-R asymmetry and so on (Kiecker \& Lumsden, 2005; Niederreither \& Dolle, 2008). It has recently been suggested that RA might also have physiological roles in cortical development at the later embryonic stages (Siegenthaler et al., 2006; Smith et al., 2001). We thus next tried to examine the possible roles of RA related cell signalling machinery in the cortical area pattering during development. By using the same BAC clone RP23-78N21, we replaced the Cdh6-ATG exon to an expression cassette for the membrane-bound form of enhanced green fluorescent protein (GAP43-EGFP) by means of homologous recombination and generated transgenic 


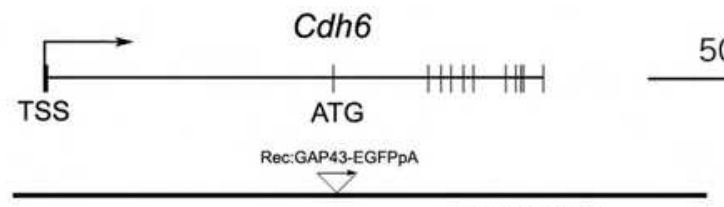

RP23-78N21
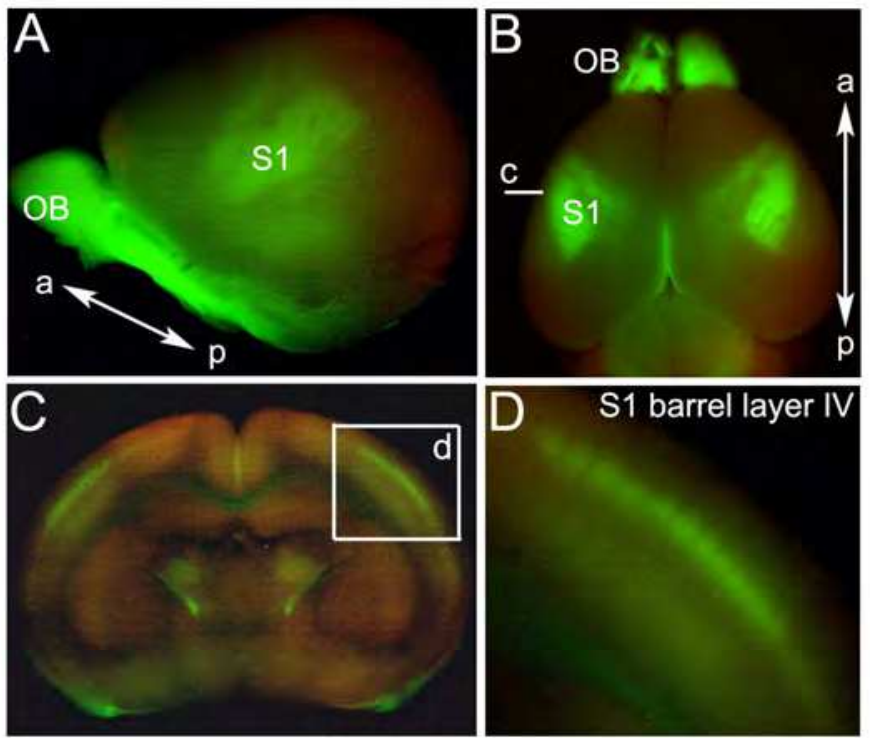

Control : P7

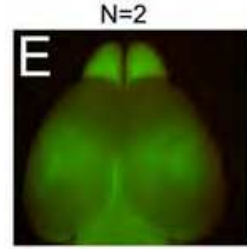

$\mathrm{RA}+\mathrm{E} 14.5: \mathrm{P7}$

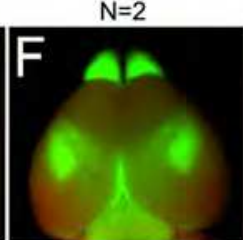

$R A+E 17.5: P 7$

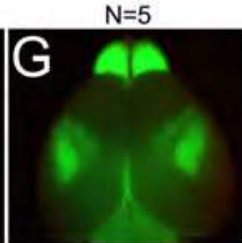

$\mathrm{RA}+\mathrm{P} 0$ : P7

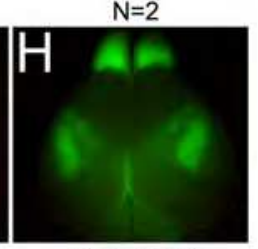

$R A+P 3: P 7$

Fig. 2. Possible involvement of retinoic acid (RA) related cell signalling machineries in the cortical barrel patterning.

A BAC clone RP23-78N21 is modified to harbour a membrane-bound form of EGFP cassette and SV40 polyadenylation signal (GAP43-EGFP-pA) in frame to the Cdh6 gene via homologous recombination (Rec) in a recombinogenic bacterial strain (upper most part of the figure). (A-D) A Tg mouse with EGFP modified BACs recapitulated Cdh6 expression at P7. OB, olfactory bulb; S1 primary somatosensory area. The boxed area $\mathrm{d}$ in panel $\mathrm{C}$ is magnified in panel D. Note that Layer IV barrels in S1 are illuminated in this Tg mouse line. (E-H) Effects of RA on barrel development. RA is intraperitoneally injected into the mother (E, F) or the pups $(\mathrm{G}, \mathrm{H})$ and the EGFP expression profile is evaluated at P7. Note that this is only the case with E14.5 injections, which affect the formation of barrel cytoarchitecture, highlighting the role of RA in early neocortical development. 
mouse founders (Inoue et al., 2009). In the Tg cerebral cortex, we found that GFP expression shows exactly the same patterns as with the original LacZ-Tg mice (Fig 1 and 2). In particular, this GFP-BAC-Tg mouse line illuminated the S1 barrel structure of the whole mount brain preparations, allowing us to easily image the S1-barrel territory whose identification generally requires specific histological staining processes, such as the $\mathrm{CO}$ staining method.

We then administrated RA to the mothers or pups for GFP-BAC-Tg, with the concentration reported to induce abnormality in the cortex (Smith et al., 2001) and evaluated how RA affects the GFP expression patterns at P7. As a result of this, no drastic change was observed for the cortical barrel patterning when RA was administrated later than embryonic day 17.5 (E17.5). However, RA administration at E14.5 resulted in massive perturbation of S1 barrel patterning, with ambiguous area boundaries illuminated by GFP expression. Noticeably, the intensity of the GFP expression appeared to be decreased due to the qualitative and quantitative differences among Cdh6::GFP positive cortical cells and/or thalamocortical axon terminals. These results imply that the role of RA in regulating Cdh6 expression and/or cortical area pattering is just limited to those embryonic stages earlier than E14.5.

It is now widely accepted that cortical area patterning begins as early as mouse E12.5 when the counter-gradient of the transcription factors Pax6 and Emx2 is established in the cortical ventricular zones (Bishop et al., 2000; Hamasaki et al., 2004). This gradation pattern, as generated by such secreted molecules as $F g f 8$, is shown to be the basis of cortical arealisation yet other transcriptional factors, such as Coup-TFI, could regulate the area-specific differentiation of distinct subtypes of cortical neurons independently of Fgf8-Pax6/Emx2 gene functions (Armentano et al., 2007; Fukuchi-Shimogori \& Grove, 2001, 2003). Our results, together with a previous series of studies, thus suggest that RA accumulated earlier than E14.5 might play a role in cortical arealisation by affecting the production, migration, positioning and/or circuit formation of the cortical S1 barrel layer IV neurons that eventually express Cdh6. The next critical step would be to examine whether RA-related signalling could be interactive with the $5,884 \mathrm{bp}$ territory identified in this study that contains RORbeta related transcription factor binding motifs.

\subsection{BACs in the field of neuroscience research}

In the present study, BAC-based methodology enabled us to systematically evaluate intricate genetic machineries in the mouse brain, highlighting the value of BAC usage in the field of neuroscience research. Recently, others have also developed many useful BACbased strategies, and here we discuss the advantages and/or future potential of some of these strategies in the field of neuroscience research.

First, we have realised that BACs must provide a useful and ideal basis in approaching the complex gene regulatory machinery that elaborates the nervous system. For instance, a difficulty involved in studying the vertebrate nervous system has lain in its complexity and, when we try to rigorously dissect its specialised structure and function, it should be an essential step in discriminating a defined group of cells among numerous neurons and glial cells. As has been demonstrated by the present study, homologous recombination-based 
systematic deletions from BAC clones combined with efficient mouse trans-genesis now allows for the quick identification of cis-regulatory elements from the huge $C d h 6$ gene locus, which contrasts with the conventional methodology where hundreds of conserved genomic regions must be evaluated one-by-one by means of plasmid-based methods (See discussions in Asami et al., 2011). A problem with this recombination-based method might lie in its limit for BAC clone usage, since the BAC clone for recombination must always include an ATG translation initiation codon for the gene of interest to achieve in-frame integration of the reporter cassette. This being the case, cis-regulatory elements located far outside of the ATGcontaining BAC clone cannot also be treated by this method. However, if combined with the transposon-based BAC modification method, one can reliably monitor the gene transcriptional activity of any BAC clones, regardless of their gene/ATG-exon coverage (Asami et al., 2011). Hence, a BAC-based strategy would greatly help the understanding of the upstream/downstream relationships among thousands of genes that are preferentially expressed in the nervous system, revealing the entire genetic programmes for building up the nervous system. Noticeably, many human single nucleotide polymorphisms (SNPs) that are tightly linked to genetic disorders have been identified in the intergenic regions (Wang et al., 2009). These SNPs are thought to play roles in regulating gene expression and/or chromosomal structures, yet the methodologies that can reliably detect their functional significance are limited in number at the present time. In this context, our BAC-based methodology could immediately serve as a steadfast platform in approaching such critical research subjects (Asami et al., 2011).

Secondly, we have demonstrated that BAC-based methodology is very useful for the stable and efficient labelling of distinct cells-types during neural development. Since fluorescent proteins - such as GFP - can easily visualise cell morphology, they have been broadly used, from basic molecular-cell biology to biomedical studies. In the field of neuroscience research, it remains a fundamental issue to thoroughly identify the original location of neurons and their partners among the billions of neurons, since they often make contact with other neurons located far away from the soma. For this purpose, the use of a membrane localisation signal, such as GAP43 tagged GFP, would clearly visualise axons, while nuclear localisation signal-based reporter introduction would precisely identify the soma location. Recently, a rabies virus mediated single synaptic transfer event was applied so as to enable systematic labelling of both the starter neurons and their primary partners in connections (Miyamichi et al., 2011). However, in order to restrict the number of neurons labelled by this method in the nervous system, it is most critical to identify enhancers/promoters that confine gene expression in the limited population of cells amongst the tens of thousands of neurons. In this context, BACs do provide an ideal resource for such an analysis because we can now easily engineer a given BAC clone to include sets of enhancers/promoters for obtaining restricted gene expression profiles, and the GENSAT project indeed generated hundreds of BAC transgenic mouse lines that differentially illuminate specific sets of cells in the nervous system (Gong et al., 2003; Gong et al., 2010). If a GFP tagged L10a ribosomal protein is expressed by BAC trans-genesis, the mRNA expressed in the specific set of cells should be illuminated and can further be isolated by the fluorescent activated cell-sorting system so as to profile their molecular characteristics (Heiman et al., 2008). 
Thirdly, a BAC-based methodology is highly expected to open a new window into the study of unknown processes for brain development and/or the functional dynamics of neural circuitries. For instance, in multicellular model organisms, such as the mouse, the fly and the nematode, loss of function studies are currently the gold standard for revealing given gene functions, contributing to the revelation of genetic programmes at the early developmental stages. There had been, however, a problem in that a simple loss of function analysis sometimes results in early embryonic lethality, preventing researchers from evaluating the gene functions in mature organs, such as brains. To circumvent this situation, a conditional gene knock-out strategy was established so that a given gene function is abolished at a defined time and place by genetically introducing the enhancer-driven site-specific recombinase $\mathrm{Cre}$ and its recognition sites LoxP sequences into the gene locus of interest. Considering their extensive coverage of various enhancers/promoters in the genome of multicellular model organisms, BAC clones should serve as the perfect starting points in the establishment of useful driver transgenic animals for conditional knock-out studies. Additionally, if the expression cassette for Cre and the estrogen receptor T2 variant fusion protein (CreERT2; Feil et al., 1997) is integrated into a proper BAC clone to generate $\mathrm{Tg}$ animals in which CreERT2 proteins are expressed among a limited group of cells, one can precisely control the timing to generate gene mutant cells by merely administrating tamoxifen, which allows selective CreERT2 localisation into the cell nuclei so as to excise the gene of interest by recombination. CreERT2-Tg animals might further be suitable for genetic cell-lineage tracing. In the mouse system, this can generally be achieved by using the reporter mouse lines, such as Rosa26R, in which LacZ reporter expression is suppressed by the intercalation of a stopper put in between the LoxP sequences. When this reporter line is mated with the CreERT2-Tg mouse line, the stopper is excised only with the administration of tamoxifen and, thereafter, a limited population of cells will be genetically and permanently marked by the reporter expression. Indeed, we have generated the Cdh6::CreERT2-BAC-Tg mouse to clarify the relationship between the Cdh6 gene expression boundary at the early cortical plate and the mature areal boundary, and have found a rigid correlation (Terakawa et al., manuscript submitted). Useful CreERT2-Tg mouse lines could be further be mated with the recently created Brainbow mouse Tg line, logically allowing the genetic labelling of individual cells in the nervous system by different fluorescent colour combinations (Livet et al., 2007). Such spatio-temporally regulated labelling of cells must aid in unveiling the functional dynamics of the nervous system in higher vertebrates with complex cellular organisation.

To finally address the fundamental question as to how the elaborated neural circuitries work in the in vivo context, the BAC-based introduction of optogenetic probes, such as channel rhodopsin and halorhodopsin, into specific sets of neurons might make it possible to selectively switch on and off neuronal activities within the regions that receive the relevant light stimuli (O'Connor et al., 2009; Zhang et al., 2007). Since the individual optogenetic probe harbours different wavelengths' selectivity, defined sets of neuronal and/or muscle activities can be manipulated by simply applying combinatorial light stimuli to the Tg animals. This technology therefore speeds the detailing of which circuitries are actually responsible for a given behaviour and/or the process for learning and memory, exemplifying how BAC-related experimental methods can be applicable to wide range of research in the field of neuroscience. 


\section{Conclusions}

Taking advantage of systematic BAC modification methodologies via homologous recombination and/or transposon tagging in bacterial cells, as well as efficient BAC transgenic strategies in various multicellular organisms, such as mice, it is now possible to mark and manipulate a given gene function amongst restricted cell groups in the nervous system at will. Given that BACs constitute the minimal components of various whole genome-sequencing projects, BAC-based technology would significantly facilitate the detail of entire genetic programmes that elaborate the complex structure and function of the nervous system, including our own. Such detailed information would greatly help the appreciation of the intricate principles of neural evolution and development, encoding, processing and/or pathogenesis.

\section{Acknowledgments}

We thank Dr. Robb Krumlauf for pBGZ40 vector and Dr. Neal G. Copeland for the recombineering related materials including EL250 bacterial stain. We also acknowledge Drs. Takayuki Sota, Shinichi Kohsaka, Keiji Wada, Mikio Hoshino and their lab members for discussions and encouragements. This work was supported by grants from Takeda Science Foundation, The Nakatomi Foundation and Research Foundation ITSUU Laboratory, Program for Promotion of Fundamental Studies in Health Sciences of the National Institute of Biomedical Innovation (05-32), and a Grant-in-Aid for Scientific Research from JSPS (\#21500333) to T. Inoue.

\section{References}

Armentano M, Chou SJ, Tomassy GS, Leingärtner A, O'Leary DD, Studer M. 2007. COUPTFI regulates the balance of cortical patterning between frontal/motor and sensory areas. Nat Neurosci. 10:1277-1286.

Asami J, Inoue YU, Terakawa YW, Egusa SF, Inoue T. 2011. Bacterial artificial chromosomes as analytical basis for gene transcriptional machineries. Transgenic Res. 20:913-924.

Bishop KM, Goudreau G, O'Leary DD. 2000. Regulation of area identity in the mammalian neocortex by Emx2 and Pax6. Science. 288:344-349.

Copeland NG, Jenkins NA, Court DL. 2001. Recombineering: a powerful new tool for mouse functional genomics. Nat Rev Genet. 2:769-779.

Dye CA, El Shawa H, Huffman KJ. 2011. A lifespan analysis of intraneocortical connections and gene expression in the mouse II. Cereb Cortex. 21:1331-1350.

Feil R, Wagner J, Metzger D, Chambon P. 1997. Regulation of Cre recombinase activity by mutated estrogen receptor ligand-binding domains. Biochem Biophys Res Commun. 237:752-757.

Fujimori T, Miyatani S, Takeichi M. 1990. Ectopic expression of N-cadherin perturbs histogenesis in Xenopus embryos. Development. 110:97-104.

Fukuchi-Shimogori T, Grove EA. 2001. Neocortex patterning by the secreted signalling molecule FGF8. Science. 294:1071-1074. 
Fukuchi-Shimogori T, Grove EA. 2003. Emx2 patterns the neocortex by regulating FGF positional signalling. Nat Neurosci. 6:825-831.

Gong S, Kus L, Heintz N. 2010. Rapid bacterial artificial chromosome modification for largescale mouse transgenesis. Nat Protoc. 5:1678-1696.

Gong S, Zheng C, Doughty ML, Losos K, Didkovsky N, Schambra UB, Nowak NJ, Joyner A, Leblanc G, Hatten ME, Heintz N. 2003. A gene expression atlas of the central nervous system based on bacterial artificial chromosomes. Nature. 425:917-925.

Gumbiner BM. 2005. Regulation of cadherin-mediated adhesion in morphogenesis. Nat Rev Mol Cell Biol. 6:622-634.

Hamasaki T, Leingärtner A, Ringstedt T, O'Leary DD. 2004. EMX2 regulates sizes and positioning of the primary sensory and motor areas in neocortex by direct specification of cortical progenitors. Neuron. 43:359-372.

Heiman M, Schaefer A, Gong S, Peterson JD, Day M, Ramsey KE, Suárez-Fariñas M, Schwarz C, Stephan DA, Surmeier DJ, Greengard P, Heintz N. 2008. A translational profiling approach for the molecular characterization of CNS cell types. Cell. 135:738-748.

Hirokawa J, Watakabe A, Ohsawa S, Yamamori T. 2008. Analysis of area-specific expression patterns of RORbeta, ER81 and Nurr1 mRNAs in rat neocortex by double in situ hybridization and cortical box method. PLoS One. 3:e3266.

Inoue T, Inoue YU, Asami J, Izumi H, Nakamura S, Krumlauf R. 2008a. Analysis of mouse Cdh6 gene regulation by transgenesis of modified bacterial artificial chromosomes. Dev Biol. 315:506-520.

Inoue T, Tanaka T, Suzuki SC, Takeichi M. 1998. Cadherin-6 in the developing mouse brain: expression along restricted connection systems and synaptic localization suggest a potential role in neuronal circuitry. Dev Dyn. 211:338-351.

Inoue YU, Asami J, Inoue T. 2008b. Cadherin-6 gene regulatory patterns in the postnatal mouse brain. Mol Cell Neurosci. 39:95-104.

Inoue YU, Asami J, Inoue T. 2009. Genetic labelling of mouse rhombomeres by Cadherin6::EGFP-BAC transgenesis underscores the role of cadherins in hindbrain compartmentalization. Neurosci Res. 63:2-9.

Jabaudon D, J Shnider S, J Tischfield D, J Galazo M, Macklis JD. 2011. ROR\{beta\} Induces Barrel-like Neuronal Clusters in the Developing Neocortex. Cereb Cortex.

Kiecker C, Lumsden A. 2005. Compartments and their boundaries in vertebrate brain development. Nat Rev Neurosci. 6:553-564.

Krishna-K, Nuernberger M, Weth F, Redies C. 2009. Layer-specific expression of multiple cadherins in the developing visual cortex (V1) of the ferret. Cereb Cortex. 19:388401.

Lee EC, Yu D, Martinez de Velasco J, Tessarollo L, Swing DA, Court DL, Jenkins NA, Copeland NG. 2001. A highly efficient Escherichia coli-based chromosome engineering system adapted for recombinogenic targeting and subcloning of BAC DNA. Genomics. 73:56-65.

Livet J, Weissman TA, Kang H, Draft RW, Lu J, Bennis RA, Sanes JR, Lichtman JW. 2007. Transgenic strategies for combinatorial expression of fluorescent proteins in the nervous system. Nature. 450:56-62. 
Miyamichi K, Amat F, Moussavi F, Wang C, Wickersham I, Wall NR, Taniguchi H, Tasic B, Huang ZJ, He Z, Callaway EM, Horowitz MA, Luo L. 2011. Cortical representations of olfactory input by trans-synaptic tracing. Nature. 472:191-196.

Nakagawa S, Takeichi M. 1998. Neural crest emigration from the neural tube depends on regulated cadherin expression. Development. 125:2963-2971.

Nakagawa Y, O'Leary DD. 2003. Dynamic patterned expression of orphan nuclear receptor genes RORalpha and RORbeta in developing mouse forebrain. Dev Neurosci. 25:234-244.

Niederreither K, Dollé P. 2008. Retinoic acid in development: towards an integrated view. Nat Rev Genet. 9:541-553.

Nose A, Nagafuchi A, Takeichi M. 1988. Expressed recombinant cadherins mediate cell sorting in model systems. Cell. 54:993-1001.

O'Connor DH, Huber D, Svoboda K. 2009. Reverse engineering the mouse brain. Nature. 461:923-929.

O'Leary DD, Chou SJ, Sahara S. 2007. Area patterning of the mammalian cortex. Neuron. 56:252-269.

Rakic P. 1988. Specification of cerebral cortical areas. Science. 241:170-176.

Redies C. 2000. Cadherins in the central nervous system. Prog Neurobiol. 61:611-648.

Siegenthaler JA, Ashique AM, Zarbalis K, Patterson KP, Hecht JH, Kane MA, Folias AE, Choe Y, May SR, Kume T, Napoli JL, Peterson AS, Pleasure SJ. 2009. Retinoic acid from the meninges regulates cortical neuron generation. Cell. 139:597-609.

Smith D, Wagner E, Koul O, McCaffery P, Dräger UC. 2001. Retinoic acid synthesis for the developing telencephalon. Cereb Cortex. 11:894-905.

Steinberg MS, Takeichi M. 1994. Experimental specification of cell sorting, tissue spreading, and specific spatial patterning by quantitative differences in cadherin expression. Proc Natl Acad Sci U S A. 91:206-209.

Suzuki SC, Inoue T, Kimura Y, Tanaka T, Takeichi M. 1997. Neuronal circuits are subdivided by differential expression of type-II classic cadherins in postnatal mouse brains. Mol Cell Neurosci. 9:433-447.

Takeichi M. 1995. Morphogenetic roles of classic cadherins. Curr Opin Cell Biol. 7:619-627.

Takeichi M, Abe K. 2005. Synaptic contact dynamics controlled by cadherin and catenins. Trends Cell Biol. 15:216-221.

Wang K, Zhang H, Ma D, Bucan M, Glessner JT, Abrahams BS, Salyakina D, Imielinski M, Bradfield JP, Sleiman PM, Kim CE, Hou C, Frackelton E, Chiavacci R, Takahashi N, Sakurai T, Rappaport E, Lajonchere CM, Munson J, Estes A, Korvatska O, Piven J, Sonnenblick LI, Alvarez Retuerto AI, Herman EI, Dong H, Hutman T, Sigman M, Ozonoff S, Klin A, Owley T, Sweeney JA, Brune CW, Cantor RM, Bernier R, Gilbert JR, Cuccaro ML, McMahon WM, Miller J, State MW, Wassink TH, Coon H, Levy SE, Schultz RT, Nurnberger JI, Haines JL, Sutcliffe JS, Cook EH, Minshew NJ, Buxbaum JD, Dawson G, Grant SF, Geschwind DH, Pericak-Vance MA, Schellenberg GD, Hakonarson H. 2009. Common genetic variants on 5p14.1 associate with autism spectrum disorders. Nature. 459:528-533. 
Zhang F, Aravanis AM, Adamantidis A, de Lecea L, Deisseroth K. 2007. Circuit-breakers: optical technologies for probing neural signals and systems. Nat Rev Neurosci. 8:577-581. 


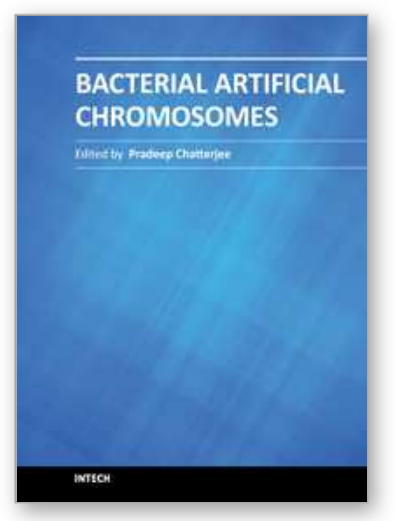

\author{
Bacterial Artificial Chromosomes \\ Edited by Dr Pradeep Chatterjee
}

ISBN 978-953-307-725-3

Hard cover, 148 pages

Publisher InTech

Published online 25, November, 2011

Published in print edition November, 2011

This book focuses on the numerous applications of Bacterial Artificial Chromosomes (BACs) in a variety of studies. The topics reviewed range from using BAC libraries as resources for marsupial and monotreme gene mapping and comparative genomic studies, to using BACs as vehicles for maintaining the large infectious DNA genomes of viruses. The large size of the insert DNA in BACs and the ease of engineering mutations in that DNA within the bacterial host, allowed manipulating the BAC-viral DNA of Varicella-Zoster Virus. Other reviews include the maintenance and suitable expression of foreign genes from a Baculovirus genome, including protein complexes, from the BAC-viral DNA and generating vaccines from BAC-viral DNA genomes of Marek's disease virus. Production of multi-purpose BAC clones in the novel Bacillus subtilis host is described, along with chapters that illustrate the use of BAC transgenic animals to address important issues of gene regulation in vertebrates, such as functionally identifying novel cis-acting distal gene regulatory sequences.

\title{
How to reference
}

In order to correctly reference this scholarly work, feel free to copy and paste the following:

Youhei W. Terakawa, Yukiko U. Inoue, Junko Asami and Takayoshi Inoue (2011). Bacterial Artificial Chromosome-Based Experimental Strategies in the Field of Developmental Neuroscience, Bacterial Artificial Chromosomes, Dr Pradeep Chatterjee (Ed.), ISBN: 978-953-307-725-3, InTech, Available from: http://www.intechopen.com/books/bacterial-artificial-chromosomes/bacterial-artificial-chromosome-basedexperimental-strategies-in-the-field-of-developmental-neurosci

\section{INTECH}

open science | open minds

\section{InTech Europe}

University Campus STeP Ri

Slavka Krautzeka 83/A

51000 Rijeka, Croatia

Phone: +385 (51) 770447

Fax: +385 (51) 686166

www.intechopen.com

\section{InTech China}

Unit 405, Office Block, Hotel Equatorial Shanghai

No.65, Yan An Road (West), Shanghai, 200040, China

中国上海市延安西路65号上海国际贵都大饭店办公楼405单元

Phone: +86-21-62489820

Fax: $+86-21-62489821$ 
(C) 2011 The Author(s). Licensee IntechOpen. This is an open access article distributed under the terms of the Creative Commons Attribution 3.0 License, which permits unrestricted use, distribution, and reproduction in any medium, provided the original work is properly cited. 